\title{
Assessment of Human-Induced Effects in the Sultan Marshes (Ramsar Protection) Kayseri (Turkey)
}

Fulya Aydin-Kandemir

Ege University Solar Energy Institute

Aynur Demir ( $\square$ aynurdemir_1@hotmail.com )

Aksaray University https://orcid.org/0000-0002-7856-2789

\section{Research Article}

Keywords: GIS, Land Use Change, Ramsar, Wetlands, Global Terrestrial Human Footprint, Human Development Index, Sultan Marshes

Posted Date: October 27th, 2021

DOI: https://doi.org/10.21203/rs.3.rs-992630/v1

License: (1) This work is licensed under a Creative Commons Attribution 4.0 International License. Read Full License 


\section{Abstract}

Sultan Marshes is one of Turkey's Ramsar wetlands and has faced significant threats in recent years. Although the water was brought from other basins for restoration, observed temporal human-induced impacts and the current drought have damaged the wetland qualities of the Marshes. In this study, the temporal change of the Marshes and the human-induced effects are analyzed. Spatiotemporal surface water area (1984-2020) and whole land use changes (1990-2018) are evaluated with the temporal change of the Human Development, Global Terrestrial Human Footprint, and Ecological Footprint Indexes. The land use changes since 1990 reveal how the wetland has lost its functions. Especially between 1990-2000, the water area largely shifted into the sandy and swampy areas. In the swampy areas between 1990-2000, natural pasture formation was also observed in 2000. In addition, it is found that mining fields were constructed in the region between 1990-2000, albeit relatively small. According to the study, the most remarkable change occurred in the 1990-2000 period, considering the entire study timeline (1990-2018). In this period, there was also a transformation into irrigated agricultural lands around the national park. Moreover, there was a transformation from orchards and pasture areas to irrigated agricultural areas. When the changes in the wetland are evaluated with the human footprint data for 1993 and 2009, it was found that human impact was more substantial, especially in 1993 compared to 2009. This is in line with the continuous increase in HDI values between 1990 (0.54) and 2018 (0.81). Besides, the ecological footprint has increased since 1983. After 1983, the biocapacity in the region has steadily decreased to negative values.

\section{Introduction}

Wetlands are one of the most biologically productive ecosystems of the earth and consist of the subject of many studies. Wetlands, suitable feeding, breeding, and sheltering environments for many species and varieties, are accepted as natural wealth museums of the countries individually and the world. Moreover, wetlands, which have many economic services in the lives of the people living in their vicinity and the country, have a meaningful and different place among other ecosystems in terms of being essential carbon sinks and protecting the natural balance and biological diversity (Biler and Altındağ 2020).

Wetlands are an indispensable habitat for many flora and fauna species, especially migratory birds. These areas are vital for oxygen in the atmosphere to be produced and organic materials to dissolve. Wetlands have significant functions such as fishing, irrigation, drinking water supply, flood control, feeding the groundwater, and scientific, educational, aesthetic, archaeological, heritage, and historical benefits that are not intended for consumption (Bürgi et al. 2017). However, these areas are threatened by many human activities that cause habitat and species loss. Mainly, anthropogenic activities such as pollution, deterioration of water balance (underground water withdrawal, deterioration of natural drainage direction, changing the direction of surface water flow, holding surface water with dams and barriers, etc.), agricultural activities, drying, filling, waste storage, industrial and residential use are significant threats to wetlands (Bergstrom and Stoll 1993; Barbier 1993; Barbier et al. 1997; Turner et al. 2000; Sönmez \& Somuncu, 2016; Biler, 2019; Biler and Altındağ 2020).

Researches reveal that wetland ecosystems, which share approximately $6 \%$ of the earth, are the most threatened areas among natural resources (Barbier et al. 1997). The destruction and loss of wetlands are appalling in almost every part of the world, especially in the Mediterranean countries. In France, there is a decrease of 10,000 ha every year. $60 \%$ of wetlands in Spain have been lost today. $80 \%$ of salty marshes in Portugal are under threat of disappearance. In Greece, $60 \%$ of the wetlands have been dried to obtain agricultural land. Wetlands have decreased by $28 \%$ in Tunisia in the last 100 years (Kence 2005; Korkanç 2005). Turkey has lost more than $50 \%$ (1,3 million ha) of wetlands throughout its history (Özesmi and Özesmi 1997; Korkanç 2005). Sultan Marshes are one of the most valuable among them, and it is trying to survive despite the problems it has been experiencing for years. Fig. 1 shows Sultan Marshes and the National Park, and Fig. 2 gives the wetland categories of the Sultan Marshes.

Sultan Marshes National Park is located 70 km south of Kayseri Province in the Central Anatolia Region, within Develi, Yeşilhisar, and Yahyalı Districts of Kayseri Province. Sultan Marshes National Park, which has an average altitude of $1071 \mathrm{~m}$, is between $38^{\circ} 12^{\prime} 14^{\prime \prime}-38^{\circ} 25^{\prime} 49^{\prime \prime} \mathrm{N}$ latitudes and $35^{\circ} 02^{\prime} 20^{\prime \prime}-35^{\circ} 22^{\prime} 20^{\prime \prime}$ E longitudes. The National Park area is $24,523 \mathrm{ha}$, and the total area, including the buffer zone, is 39,057 ha (Aksoy 2012).

Sultan Marshes are located in the center of the Develi Closed Basin with a catchment area of 319,000 km². Erciyes Mountain, an extinct volcano with a height of $3,916 \mathrm{~m}$, is in the northeast of the wetland. The area consists of fresh, salty, slightly salty lakes and swamp ecosystems. The main lakes are Yay Lake $\left(3,650 \mathrm{~km}^{2}\right.$, maximum depth $1.5 \mathrm{~m}$, with two islands) and Çöl Lake $\left(2,600 \mathrm{~km}^{2}\right)$, which dries up heavily in summer. In its natural condition, Sultan Marshes are fed by Yahyalı, Develi, Ağcaşar and Yeşilhisar streams; Soysallı, Çayırözü and Yerköy springs and groundwater (Özesmi et al. 1993; Sönmez and Somuncu 2016; KTB 2021).

Develi Plain, where the Sultan Marshes are located, is in a closed basin. Therefore, Sultan Marshes is not a swamp but insurance that allows the ecosystem to live and prevents floods and overflows in the plain. Here, most of the protected area is owned and managed by the state. The local communities carry agricultural activities and reed cutting (Özesmi et al. 1993; KTB 2021). 
Sultan Marshes National Park is a rare wetland habitat of international importance due to the coexistence of fresh and saltwater ecosystems. It is also critical due to its rich flora and fauna diversity (Aksoy 2012; Sönmez and Somuncu 2016).

In the Sultan Marshes, $11.6 \%$ (50 species) of the 430 natural plant species located within the steppe ecosystem are endemic. Especially, salty lakes are surrounded by sea cowpea (Salicornia) steppes. The swamps in the south consist mainly of Phragmites and Typha, Juncus, and Carex species (Aksoy 2012).

Among its fauna richness, bird species have the particular status for the Sultan Marshes because the marshes are located at the intersection of two significant bird migration routes passing through Turkey between Africa - Europe - Asia every year. Therefore, it has a vibrant species diversity as it provides different incubation, feeding, breeding, accommodation, and shelter. It is estimated that 600,000 water birds settled in the Sultan Marshes and their surroundings during the periods when the ecosystem features in the Marshes were close to perfect. According to the bird counting results, three hundred one bird species have been identified in Sultan Marshes (Özesmi et al. 1993; Turan et al. 1995; KTB 2021). Little cormorant, tawny heron, paddy egret, spoonbill, gray duck, summer duck, Hungarian duck, mottled duck, goose tail, crane, axilla, swamp swallow, maple plover, great plover, spur lapwing, laughing tern, little tern, and whiskered tern are among the valuable species. Angit prefers the area in the summer, while many flamingos, cranes, and apricots use the area in the fall. Many waterfowl (130,000 species) are found in winter and during migration (KTB 2021).

The Marshes are essential for birds and the flora and fauna that feed and shelter them. Although it has not been thoroughly studied in the region, over 90 plankton species, 60 species of insects, 19 species of mollusks, ten species of reptiles, three species of amphibians, 21 species of mammals, and 174 plant species have been identified (Özesmi et al. 1993). Part of the marshes in the north (partly irrigated) has been converted into the grain, sugar beet, and sunflower fields. In addition, sheep are grazed in the surrounding steppes, and cattle are grazed in swampy areas (KTB 2021).

Sultan Marshes is one of the areas with the highest protection status in Turkey. In 1971, an area of 45,000 hectares in the region was reserved as a Wildlife Protection Area. An area of 17,200 hectares was given the status of Nature Protection Area in 1988 and the natural protected (SIT) area in 1993. In 1994, the 17,200 km² area was selected as one of Turkey's first five Ramsar sites. In 2006, the protection status of the Sultan Marshes was changed and declared as a National Park. The last two statuses are based on the Nature Conservation Area borders, which do not include the Çöl Lake and most nearby steppes (Sönmez and Somuncu 2016; KTB 2021). In the 1950s, a part of the Kepir Marshes in the north was distributed to the villagers by the state. These 1,900 hectares of the Marshes, which are within the borders of the Nature Conservation Area, have been largely converted into agricultural land and pasture in the recent period. Today, a maximum of 500 hectares of the Marshes preserve their natural characteristics (KTB 2021).

There are many studies in the literature about the Sultan Marshes. Dadaser-Celik et al. (2008) demonstrated the change in Sultan Marshes between 1980-2003 with satellite images. The analysis showed that lake surface areas decreased by $93 \%$ from 1980 to 2003 . Yay Lake was almost completely dry in 2003 . The marshes receded more than $50 \%$, and the surrounding steppe expanded into the lakes and marshes. Agriculture expanded in the western and eastern parts (Kepir Marshes) of the study area. Although the years 2000 and 2003 had lower than average annual precipitation and lower annual precipitation than in 1980 and 1987, the changes in Sultan Marshes are so significant that they cannot be solely attributed to weather fluctuations. According to the authors, surface water diversions, increased use of spring waters, and groundwater are responsible for the changes. Kesikoglu et al. (2019) focused on the changes from 2005 to 2012 in the Sultan Marshes. It was observed that marshes and steppe areas decreased while water and agricultural areas expanded from 2005 to 2012 . These changes could be the results of water transfers to the marshes from the neighboring watershed.

Sultan Marshes wetland, a valuable Ramsar area in the arid, semi-arid region, is one of the areas in Turkey where the pressure of anthropogenic processes on wetlands can be observed most clearly. Therefore, it was chosen as the subject of study. This study aims to reveal the anthropogenic pressures on the Sultan Marshes the vulnerabilities of the wetland. In this study, land use/cover flows between 1990 and 2018 were evaluated in the Sultan Marshes, and these changes were analyzed together with other anthropogenic impacts. Considering Sultan Marshes and all wetlands under the same conditions, one of the terrifying facts today is that wetlands can be dragged into irreversible circumstances when the observed anthropogenic impacts are combined with climate change.

\section{Material And Method}

In this study, human-induced impacts on the Sultan Marshes were examined. The data framework of the study is given in Fig. 3.

In the study, the Sultan Marshes were examined together with some human-induced factors. These factors are;

- Human Development Index: The Subnational Human Development Index (SHDI) was constructed by the Global Data Lab (GDL) at the Institute for Management Research at Radboud University (R.U.) (Smits et al. 2018). The index measures the average subnational values for three dimensions of subnational human development: education, health, and standard of living for the period 1995-2018.

Page $3 / 18$ 
- Global Terrestrial Human Footprint: The global human footprint map, created by Venter et al. (2016a;b;c), used the human footprint framework to compile remotely sensed and bottom-up survey information on eight variables measuring the direct and indirect human pressures on the environment in 1993 and 2009.

- Ecological Footprint: Biologically productive land and water area are required for an ecosystem to produce the resources a population consumes and absorb the waste it generates. The Ecological Footprint of Consumption data set, released by the Global Footprint Network, defines the area to support a defined population's consumption (Freiwald et al. 2017).

- Landuse / Landcover Change: For this study, land use change (CHA) data are obtained from the CORINE database (CORINE 2021) as vector layers for 1990-2000, 2000-2006, 2006-2012, and 2012-2018.

The anthropogenic factors included here were evaluated with the surface water occurrence change intensity values obtained from the European Commission Joint Research Centre's Global Surface Water Datasets (1984 to 2020) (Pekel et al. 2016).

\section{Results And Discussions: Human-induced Effects On The Sultan Marshes With Spatiotemporal Surface Water Changes}

Landuse / Landcover Change: Landcover plays a significant role in the climate and biogeochemistry of the Earth system. Understanding patterns in land use and alterations of land cover classes over time is essential to recognize, monitor, and manage several processes at the global level. Therefore, accurate and spatially detailed maps on land cover and land use are relevant to a broad range of issues, including deforestation, desertification, urbanization, land degradation, loss of biodiversity and ecosystem functions, water resource management, agriculture and food security, urban and regional development, and climate change and are critical to make informed policy development, planning, and resource management decisions (Buchhorn et al. 2020).

In this study, the land use/cover data were attained from the Coordination of Information on the Environment (CORINE) Land Cover (CLC) inventory, which was initiated in 1985 (the reference year 1990). Updates have been produced in 2000, 2006, 2012, and 2018. It consists of an inventory of land cover in 44 classes (CORINE 2021). For this study, land use change (CHA) data are obtained from the CORINE database as vector layers for 1990-2000, 2000-2006, 2006-2012, and 2012-2018. The LULC classes are also considered based on these CORINE layers, as given in Table 1. The CHAs of the study area were also shown in Fig 4 and Fig 5. 


\begin{tabular}{|c|c|}
\hline CORINE Code & CORINE Land Use Description \\
\hline 111 & Continuous urban fabric \\
\hline 112 & Discontinuous urban fabric \\
\hline 121 & Industrial or commercial units \\
\hline 133 & Construction sites \\
\hline 142 & Sport and leisure facilities \\
\hline 122 & Road and rail networks and associated land \\
\hline 124 & Airports \\
\hline 211 & Non-irrigated arable land \\
\hline 212 & Permanently irrigated land \\
\hline 242 & Complex cultivation patterns \\
\hline 243 & Land principally occupied by agriculture, with significant areas of natural vegetation \\
\hline 221 & Vineyards \\
\hline 222 & Fruit trees and berry plantations \\
\hline 223 & Olive groves \\
\hline 311 & Broad-leaved forest \\
\hline 312 & Coniferous forest \\
\hline 313 & Mixed forest \\
\hline 231 & Pastures \\
\hline 321 & Natural grasslands \\
\hline 323 & Sclerophyllous vegetation \\
\hline 324 & Transitional woodland-shrub \\
\hline 331 & Beaches, dunes, sands \\
\hline 332 & Bare rocks \\
\hline 333 & Sparsely vegetated areas \\
\hline 334 & Burnt areas \\
\hline 131 & Mineral extraction sites \\
\hline 132 & Dump sites \\
\hline 411 & Inland marshes \\
\hline 512 & Water bodies \\
\hline 523 & Sea and ocean \\
\hline
\end{tabular}




\begin{tabular}{|c|c|c|c|c|c|c|c|c|c|c|c|c|c|c|c|}
\hline $\mathrm{CHA}$ & 1990 & 2000 & $\begin{array}{l}\text { Area } \\
\text { (ha) }\end{array}$ & $\mathrm{CHA}$ & 2000 & 2006 & $\begin{array}{l}\text { Area } \\
\text { (ha) }\end{array}$ & $\mathrm{CHA}$ & 2006 & 2012 & $\begin{array}{l}\text { Area } \\
\text { (ha) }\end{array}$ & CHA & 2012 & 2018 & $\begin{array}{l}\text { Area } \\
\text { (ha) }\end{array}$ \\
\hline $\begin{array}{l}222- \\
212\end{array}$ & 222 & 212 & 173 & $\begin{array}{l}211- \\
212\end{array}$ & 211 & 212 & 35 & $\begin{array}{l}231- \\
211\end{array}$ & 231 & 211 & 19 & $\begin{array}{l}133- \\
121\end{array}$ & 133 & 121 & 12 \\
\hline $\begin{array}{l}222- \\
231\end{array}$ & 222 & 231 & 89 & $\begin{array}{l}212- \\
211\end{array}$ & 212 & 211 & 37 & $\begin{array}{l}231- \\
212\end{array}$ & 231 & 212 & 284 & $\begin{array}{l}212- \\
221\end{array}$ & 212 & 221 & 77 \\
\hline $\begin{array}{l}231- \\
112\end{array}$ & 231 & 112 & 82 & $\begin{array}{l}231- \\
212\end{array}$ & 231 & 212 & 65 & $\begin{array}{l}331- \\
512\end{array}$ & 331 & 512 & 82 & $\begin{array}{l}231- \\
212\end{array}$ & 231 & 212 & 160 \\
\hline $\begin{array}{l}231- \\
212\end{array}$ & 231 & 212 & 45 & $\begin{array}{l}321- \\
212\end{array}$ & 321 & 212 & 13 & $\begin{array}{l}333- \\
131\end{array}$ & 333 & 131 & 8 & $\begin{array}{l}231- \\
212\end{array}$ & 231 & 212 & 143 \\
\hline $\begin{array}{l}321- \\
112\end{array}$ & 321 & 112 & 6 & $\begin{array}{l}333- \\
212\end{array}$ & 333 & 212 & 9 & $\begin{array}{l}333- \\
512\end{array}$ & 333 & 512 & 46 & $\begin{array}{l}333- \\
121\end{array}$ & 333 & 121 & 24 \\
\hline $\begin{array}{l}321- \\
121\end{array}$ & 321 & 121 & 28 & $\begin{array}{l}512- \\
331\end{array}$ & 512 & 331 & 2598 & & & & & $\begin{array}{l}333- \\
131\end{array}$ & 333 & 131 & 5 \\
\hline $\begin{array}{l}331- \\
121\end{array}$ & 331 & 121 & 19 & $\begin{array}{l}512- \\
411\end{array}$ & 512 & 411 & 906 & & & & & $\begin{array}{l}411- \\
212\end{array}$ & 411 & 212 & 99 \\
\hline $\begin{array}{l}331- \\
243\end{array}$ & 331 & 243 & 57 & & & & & & & & & & & & \\
\hline $\begin{array}{l}333- \\
131\end{array}$ & 333 & 131 & 21 & & & & & & & & & & & & \\
\hline $\begin{array}{l}411- \\
321\end{array}$ & 411 & 321 & 752 & & & & & & & & & & & & \\
\hline $\begin{array}{l}512- \\
331\end{array}$ & 512 & 331 & 192 & & & & & & & & & & & & \\
\hline $\begin{array}{l}512- \\
411\end{array}$ & 512 & 411 & 2356 & & & & & & & & & & & & \\
\hline
\end{tabular}

According to Fig 4, Fig 5, and Table 2, the land use change analysis can be discussed in four periods below.

1990-2000: Significant changes are observed in terms of land use in the region. Especially between 1990-2000, the water area has largely left sandy and swampy areas. In the areas that were swampy at that time, natural pasture formation was observed in 2000 . This situation can be explained by the water turning into a swamp and then wholly drying and turning into sand or natural pasture. It is also seen that mining fields were constructed in the region between 1990-2000, albeit relatively small. In general, the most remarkable change occurred between the years 1990-2000. In this period, there was also a transformation into irrigated agricultural lands around the national park. There is a transformation from orchards and pasture areas to irrigated agricultural areas. Also, it was determined that an area of 82 hectares in the east of the wetland transitioned to the urban area.

2000-2006: The period in which Yay Lake, located in the Sultan Marshes, completely transformed into a sandy structure was between 20002006. Yay Lake, located in the Natural Park, dried up in this period.

2006-2012: There was no high change in this period like other periods. During this period, some pastures (303 ha) were converted into agricultural land. Apart from this, water is seen in sandy areas but in minimal.

2012-2018: This period was again when some pasture lands were converted into agricultural areas. Some marshy areas have also been turned into agricultural areas.

Global Surface Water Occurrence Change Intensity: The European Commission Joint Research Centre 'Global Surface Water Datasets' (Global Surface Water Explorer 2020) comprehend maps of surface water location and temporal distribution from 1984 to 2020 and offer statistics on the extent and change of those water surfaces. Enhances in water occurrence are shown in green, and reductions are indicated in red. Black areas are those areas where there is no considerable change in the water occurrence during the 1984-2020 period. The concentration of the color symbolizes the degree of change (as a percentage). For example, bright red areas show a more significant water loss than light red areas (Pekel et al. 2016). The spatiotemporal change in the surface water area of Yay Lake and Çöl Lake in the Sultan Marshes is given in Fig 6.

Temporal change of land use/cover around the Sultan Marshes is one of the human-induced effects around the wetland. The changes in Fig 6 show that Yay Lake dried up to a large extent between 1984 and 2020. Çöl Lake has dried up in the same way. This can be expressed as the shift 
from water bodies to swampy areas and then to sandplains (especially in 1990-2000), as in Fig 4 and Fig 5. The withdrawal of water, one of the most vital ecosystems of the Sultan Marshes, requires more meaningful perspectives in which other factors in the region are also evaluated.

Human Development Index: Subnational Human Development Index for the period 1995-2018, which measures the average subnational values for three dimensions of human development: education, health, and standard of living. In its official version defined at the national level, these dimensions are measured with the following indicators: Education measured with the variables' Mean years of schooling of adults aged $25+$ and 'Expected years of schooling of children aged 6'; health measured with 'Life expectancy at birth' and standard of living measured with 'Gross National Income per capita'. This dataset is translated from the United Nations Development Programme's (UNDP) official Human Development Index (HDI) to the subnational level using subnational values retrieved from the Area Database of the Global Data Lab, national statistical offices, and the E.U. statistical office (Eurostat) (Smits et al. 2018).

HDI, initially calculated for U.N. member states in 1975, is arguably the most widely used for 182 countries using a consistent framework. The HDI is comprised of four component indices to measure three development dimensions: (1) quality of life, (2) education levels, and (3) standard of living. The component indices to measure these dimensions are life expectancy for (1), expected and mean years of schooling for (2), and GNI-per-capita for (3) (Susnik and van der Zaag 2017). For the Central Anatolia (Kayseri, Kirsehir, Nevsehir, Nigde, Sivas, Yozgat, Aksaray, Kirikkale), the HDI values between 1990 and 2018 were given in Fig 7.

HDI values in this region increased from 0.54 to 0.81 between 1990 and 2018 . The results show that the standard of living in the region has risen. The rising standard of living means that people demand more and more basic needs such as water, electricity, and food products. However, according to UNDP reports, no country or no city has achieved high human development without causing significant environmental harm (Development and Cooperation 2021). According to Susnik and van der Zaag (2017), HDI is tightly linked to the economy and personal resource use. For example, the authors considered access to safe drinking water (as a percentage of the total population), and strong correlations were identified between water use and HDI. This situation also supports that the increased HDI is associated with the amount of water withdrawn for domestic water use and agricultural irrigation in the region.

Global Terrestrial Human Footprint: The global human footprint map, created by Venter et al. (2016), includes data on (1) extent of built environments, (2) cropland, (3) pastureland, (4) human population density, (5) nighttime lights, (6) railways, (7) roads, and (8) navigable waterways. These pressures were weighted according to estimates of their relative levels of human pressure and then summed together to create the standardized human footprint for all non-Antarctic land areas at $1 \mathrm{~km}$ resolution (Venter et al. 2016a;b;c). The HFP values for 1993 and 2009 were shown in Fig 8.

In the 1990-2000 period, the water area gradually turned into sand and swamp when the land use change analysis was considered. Harmoniously, the study found that the change in HFP in 1993 was higher than in 2009 in the region. Here, the change of the different land use classes increased the human footprint in the region. In 1990-2000 period, the tremendous change was between water bodies and inland marshes (CORINE codes 512 to 411; 2356 ha, Table 2). The other land use /cover changes were inland marshes (411) to natural grasslands (321) (752 ha), water bodies (512) to sandplains (331) (192 ha), sandplains (331) to land occupied by agriculture (243) (57 ha) and pastures (231) to irrigated land (212) (45 ha) (see Table 2).

The human footprint of 2009 is lower than 1993 because the water was entirely replaced by dunes and swamps between 2000-2006. In the 2006-2012 period, only some of the land use /cover classes were transitioned in minimal but stimulating: Pastures (231) to irrigated agriculture (212) (284 ha), sandplains (331) to water bodies (512) (82 ha), pastures (231) to rainfed agriculture (211) (19 ha) and sparsely vegetated areas (333) to mining sites (131) (8 ha). The human footprint in the region's center was low in 2009 because the water dries up entirely between 2000 2006, and there was no change in this area until 2009.

Ecological Footprint: In the Ecological Footprint of Consumption data set, released by the Global Footprint Network, the consumption Footprint in global hectares (ha) includes the area needed to produce the materials consumed and the area needed to absorb the $\mathrm{CO}_{2}$ emissions. The consumption footprint of a nation is calculated in the National Footprint Accounts as a nation's primary production footprint plus the footprint of imports minus the footprint of exports. It is thus, strictly speaking, a footprint of apparent consumption. The national average per capita consumption footprint equals a country's consumption footprint divided by its population (Freiwald et al. 2017).

For Turkey, 2017 Ecological Footprint per person was found as 3.5 from Global Footprint Network. In 1961 this value was 1.56 . Biocapacity per person was 1.4 in 2017, while it was 2.7 in 1961. In 2017, the biocapacity (reserve (+)/deficit(-)) was found as -2.1 (Fig 9 ). Here, biocapacity is a measure of the capacity of ecosystems in a geographical region to produce renewable natural resources and absorb waste. Two factors determine a region's biological capacity: the area of biologically productive land and water (cropland, grazing land, forests, urban areas, fishing grounds) and the productivity of these areas (Footprint Network 2021).

In Fig 9, the global hectare represents a hectare of bioproductive land with the world average ability to provide services to humanity. Thus, a global hectare is the unit of calculation of both Ecological Footprint and biocapacity. This standard metric compares resource use and

Page $7 / 18$ 
availability and compares resource accounts across different land use types.

The ecological footprint of Turkey represents an indication of a globally unsustainable lifestyle in the country. According to Footprint Network report (2021), the total Ecological Footprint had surpassed the countrywide biocapacity for the first time in 1974, just as the National Footprint and Biocapacity Accounts database (Fig 9). In the reports, the main reason for the countries ecological debt is population growth. As revealed in this study, when HDI increment in the study area combined with the rising population, the footprint also increases, as stated in the reports (Footprint Network 2021). Therefore, the general situation of the country can also be expressed for the study area.

\section{Conclusion}

With the narrowing of the water surface area in the Sultan Marshes, it is seen that the areas utterly devoid of vegetation have increased significantly. Therefore, it is possible to say that there is a relationship between the increase in plant-free surfaces with (1) destruction of the natural vegetation around the reed area, (2) consumption of groundwater, and (3) land use.

Significant decline of steppe areas (pastures) and areal expansion in irrigated and rainfed agricultural areas exacerbate erosion in the study area and its surroundings. This situation causes the sandplains to expand rapidly, and the agricultural and residential areas adversely affected by sandstorms. Suppose the increase in agricultural activities and the drying of water areas continue. In that case, the Sultan Marshes, one of Turkey's critical ecosystems, will risk losing the importance of its biological diversity.

Therefore, the most remarkable factors in the loss of wetland functions of the Sultan Marshes are human activities. These activities, when combined with climate change, make the wetland even more vulnerable. These problems are like the chronic problems of wetlands throughout

Turkey. In order to eliminate these problems and protect not only wetlands but also all natural areas, the impact on ecosystem services should be considered in cost-benefit analyses used to help make decisions regarding land use policies and construction permits in Turkey and around the world. Thus, the value of ecosystem services that currently have no market value can be considered; excessive damage to natural systems and ecosystem services can be avoided. As Dadaser Çelik (2021) stated, considering the future climate change impacts, the most vital thing for the Sultan Marshes in dryland is to perform water management at the basin scale and perhaps on a larger scale and with a more holistic approach. Water is used for agriculture, domestic needs, and industrial purposes. Most of the time, the water needs of ecosystems are neglected in planning. In order not to destroy vitally essential ecosystems such as the Sultan Marshes and not to insert into an irreversible path, the water needs of wetlands should also be included in the planning activities.

\section{Declarations}

\section{Author contributions}

Conceptualization: Fulya Aydin-Kandemir; Methodology: Fulya Aydin-Kandemir; Formal analysis and investigation: Fulya Aydin-Kandemir; Writing - original draft preparation: Fulya Aydin-Kandemir, Aynur Demir; Writing - review and editing: Fulya Aydin-Kandemir; Funding acquisition: No funding obtained.

\section{References}

1. Aksoy A (2012) Sultan Sazlığı Milli Parkı'nda Floranın Biyokıymetlendirilmesi. In: Bilgin A, Doğan M (Eds) Doğa Korumanın Ekonomik Sisteme Entegrasyonu Taslak Kılavuzu 2 Biyokıymetlendirme Teknik Uygulayıcıları: Sultan Sazlığı Milli Parkı Pilot Uygulaması. Taha Grup Kırtasiye, 1. Basım, Ankara [In Turkish]

2. Barbier EB (1993) Sustainable use of wetlands - valuing tropical wetland benefits: Economic methodologies and applications. Geogr. J 159:22-32. http://dx.doi.org $\backslash 10.2307 / 3451486$

3. Barbier EB, Acreman MC, Knowler D (1997) Economic valuation of wetlands: A guide for policy makers and planners. Appendix 1-Wetland Components, Functions and Attributes and their Human Uses. Ramsar Convention Bureau, Gland, 138 pp

4. Bergstrom JC, Stoll JR (1993) Value estimator models for wetlands-based recreational use values. Land Econ 69(2):132-137. https://doi.org/10.2307/3146513

5. Biler L (2019) Sulak Alanlar, Değer Biçme ve Türkiye'ye Özgü Yöntem Belirlenmesi ve Balıkdamı Sulak Alanında Uygulanması (Doktora Tezi). Ankara Üniversitesi, Ankara, Türkiye [In Turkish]

6. Biler L, Altındağ A (2020) Wetland valuation methods. Comm J Biol 4(1):76-81. DOI:10.31594/commagene.711156

7. Buchhorn M, Lesiv M, Tsendbazar NE, Herold M, Bertels L, Smets B (2020) Copernicus Global Land Cover Layers - Collection 2. Remote Sensing 12(108):1044. DOI 10.3390/rs12061044. Accessed through Resource Watch. www.resourcewatch.org

8. Bürgi M, Östlund L, Mladenoff DJ (2017) Legacy effects of human land use: Ecosystems as time-lagged systems. Ecosystems 20(1):94103. https://doi.org/10.1007/s10021-016-0051-6 
9. CORINE (2021) https://land.copernicus.eu/pan-european/corine-land-cover. Access Date: 20.05.2021

10. Dadaser-Celik F, Bauer ME, Brezonik PL, Stefan HG (2008) Changes in the Sultan Marshes ecosystem (Turkey) in satellite images 19802003. Wetlands 28(3):852-865. https://doi.org/10.1672/07-182.1

11. Dadaser Çelik F (2021) Yay Gölü'nde eylülde de kuraklık hakim. https://www.aa.com.tr/tr/cevre/yay-golunde-eylulde-de-kuraklikhakim/2372731. Access Date: 23.09.2021 [In Turkish]

12. Development and Cooperation (2021) Environmentally enhanced Human Development Index. https://www.dandc.eu/en/article/responsedramatic-risks-undp-now-considers-environmental-aspects-modified-human-development. Access Date 05.09.2021

13. Doğal Koruma ve Milli Parklar (2021) https://www.arcgis.com/apps/View/index.html?appid=5f3978146c4643438ab446620e275269. Access Date 10.08.2021

14. Footprint Network (2021) Executive Summary: Turkey's Ecological Footprint Report. https://www.footprintnetwork.org/content/images/uploads/Turkey_Ecological_Footprint_Report_Executive_Summary-Conclusion.pdf. Access Date: 01.09.2021

15. Freiwals A, Rogers A, Hall-Spencer J, Guinotte JM, Davies AJ, Yesson C, Martin CS, Weatherdon LV (2017) Global distribution of cold-water corals (version 3.0). UNEP-WCMC. Retrieved from http://data.unep-wcmc.org/data sets/3, September 15, 2017. Accessed through Resource Watch. www.resourcewatch.org

16. Global Surface Water Explorer (2020) https://global-surface-water.appspot.com/. Access Date: 12.06.2021

17. Kence M (2005) The Conservation of Wetlands. http://business.hol.gr/bio/HTML/PUBS/VOL5/html/kenm_tur.htm. Access date: 15.09 .2021

18. Kesikoglu MH, Atasever UH, Dadaser-Celik F, Ozkan C (2019) Performance of ANN, SVM and MLH techniques for land use/cover change detection at Sultan Marshes wetland, Turkey. Water Sci Technol 80(3):466-477. https://doi.org/10.2166/wst.2019.290

19. Korkanç YS (2005) Kurak ve Yarıkurak Bölgelerde Sulak Alanların Varlığını Tehdit Eden Unsurlar. Korunan Doğal Alanlar Sempozyumu, 8-10 Eylül 2005, SDÜ, Isparta [In Turkish]

20. KTB (Kültür ve Turizm Bakanlığı) (2019) Kayseri İl Kültür ve Turizm Müdürlüğü. https://kayseri.ktb.gov.tr/TR-183204/sultan-sazligi.html [In Turkish]

21. Lehner B, Döll P (2004) Development and validation of a global database of lakes, reservoirs and wetlands. J Hydrol 296/1-4:1-22

22. National Footprint and Biocapacity Accounts (2021) (Data Year 2017) GDP, World Development Indicators, The World Bank 2020; Population, U.N. Food and Agriculture Organization

23. Özesmi U, Somuncu M, Tunçel H (1993) Ecosystem of Sultan Marshes. Ankara Üniversitesi Turkiye Cografyasi Araştırma ve Uygulama Merkezi Turkiye Cografyası Dergisi 275-289

24. Özesmi U, Özesmi SL (1997) Amerika Birleşik Devletleri'nde Sulak Alan Tanımı ve Korunması: Türkiye lçcin Getirdikleri, III. Ulusal Ekoloji ve Çevre Kongresi, Ağustos, Kırşehir. http://env.erciyes.edu.tr/abstracts/abstract-turkwet.html [In Turkish]

25. Pekel JF, Cottam A, Gorelick N, Belward AS (2016) High-resolution mapping of global surface water and its long-term changes. Nature 540:418-422. doi:10.1038/nature20584

26. Smits J, Permanyer I (2018) Subnational Human Development Database. Global Data Lab, Global Data Lab. hdi.globaldatalab.org/areadata/. Accessed through Resource Watch, www.resourcewatch.org

27. Sönmez ME, Somuncu M (2016) Evaluation of spatial change in the Sultan Marshes in terms of sustainability. Türk Coğrafya Dergisi 66:110. https://doi.org/10.17211/tcd. 70341

28. Susnik J, van der Zaag P (2017) Correlation and causation between the UN Human Development Index and national and personal wealth and resource exploitation. Economic Research-Ekonomska Istraživanja 30(1):1705-1723. DOI:10.1080/1331677X.2017.1383175

29. Turan L, Erdoğan A, Kiziroğlu i (1995) Sultan Sazlıgının Yönetım Planı Alanın Ornitolojik Açıdan Son Durumu. Hacettepe Universitesi Eğitim Fakültesi Dergisi 11:49-56 [In Turkish]

30. Turner RK, van den Bergh JCJM, Söderqvist T, Barendregt A, van der Straaten J, Maltby E, van lerland EC (2000) Special issue: The values of wetlands: Landscape and institutional perspectives. Ecological-economic analysis of wetlands: Scientific integration for management and policy. Ecol Econ 35:7-23. https://doi.org/10.1016/S0921-8009(00)00164-6

31. Venter O, Sanderson EW, Magrach A, Allan JR, Beher J, Jones KR, Possingham HP, Laurance WF, Wood P, Fekete BM, Levy MA, Watson JEM (2016) Data from: Global terrestrial Human Footprint maps for 1993 and 2009, Dryad, Dataset, https://doi.org/10.5061/dryad.052q5

32. Venter O, Sanderson EW, Magrach A, Allan JR, Beher J, Jones KR, Possingham HP, Laurance WF, Wood P, Fekete BM, Levy MA, Watson JEM (2016) Global Terrestrial Human Footprint Maps for 1993 and 2009. Scientific Data 3: 160067. http://dx.doi.org/10.1038/sdata.2016.67. Accessed through Resource Watch. www.resourcewatch.org

33. Venter O, Sanderson EW, Magrach A, Allan JR, Beher J, Jones KR, Possingham HP, Laurance WF, Wood P, Fekete BM, Levy MA, Watson JEM (2016) Data from Global Terrestrial Human Footprint Maps for 1993 and 2009. Dryad Digital Repository. http://dx.doi.org/10.5061/dryad.052q5.2. Accessed through Resource Watch. www.resourcewatch.org

Page $9 / 18$ 
Figures

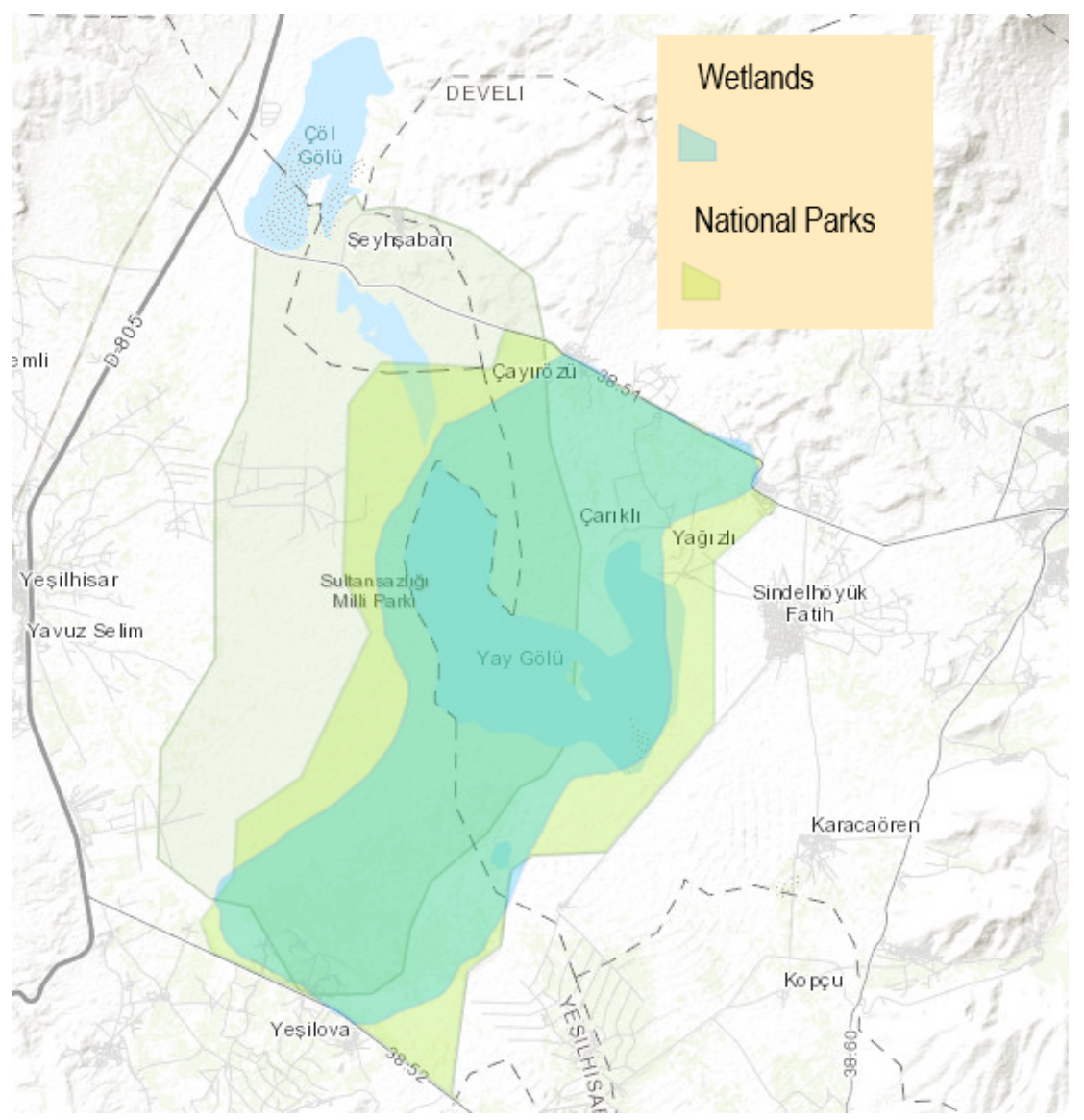

\section{Figure 1}

Sultan Marshes and National Park (Source: Doğal Koruma ve Milli Parklar 2021; https://www.arcgis.com/apps/View/index.html? appid=5f3978146c4643438ab446620e275269). 


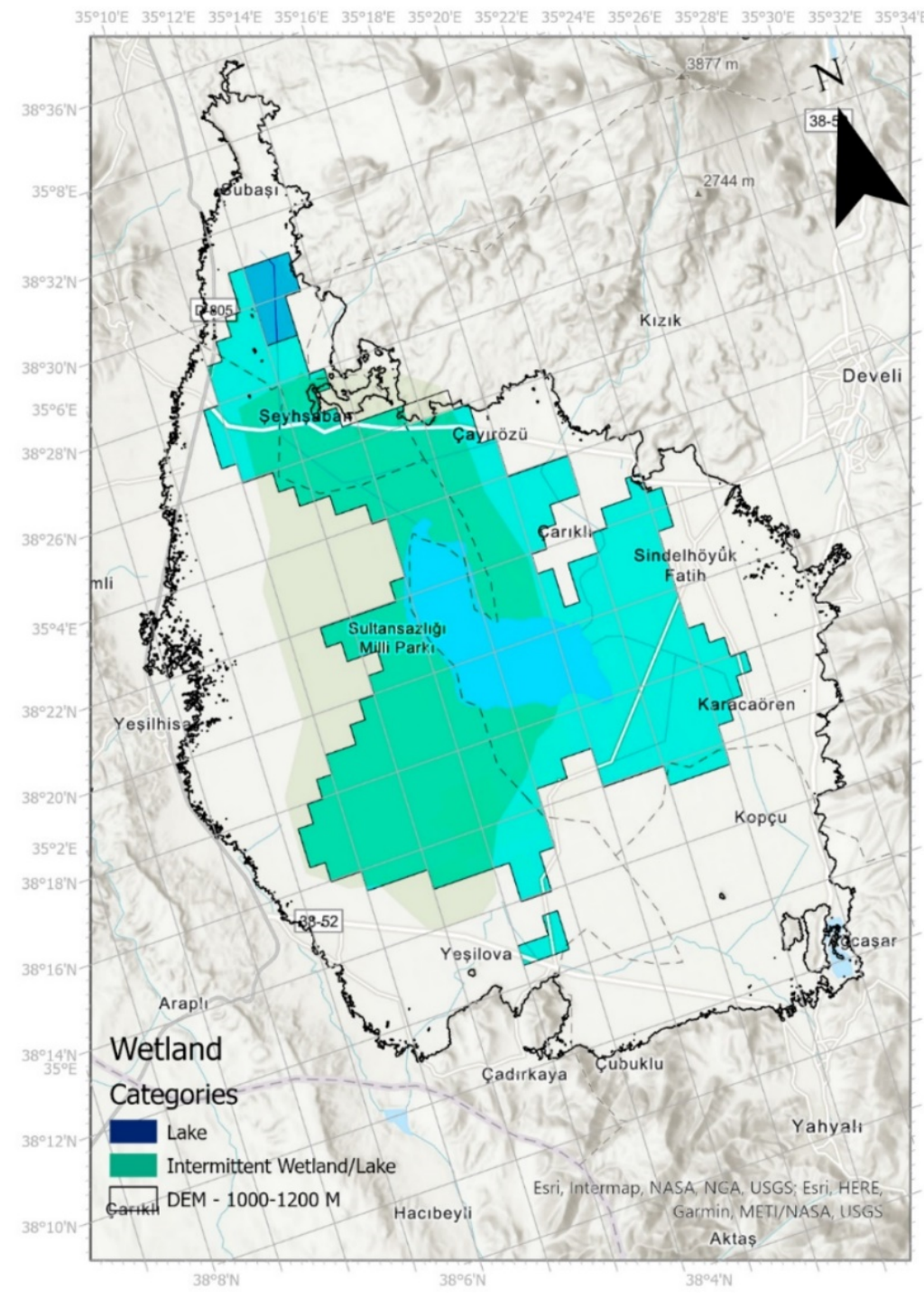

\section{Figure 2}

Wetland categories based on World Wide Fund (Lehner and Döll 2004) for the Sultan Marshes. 


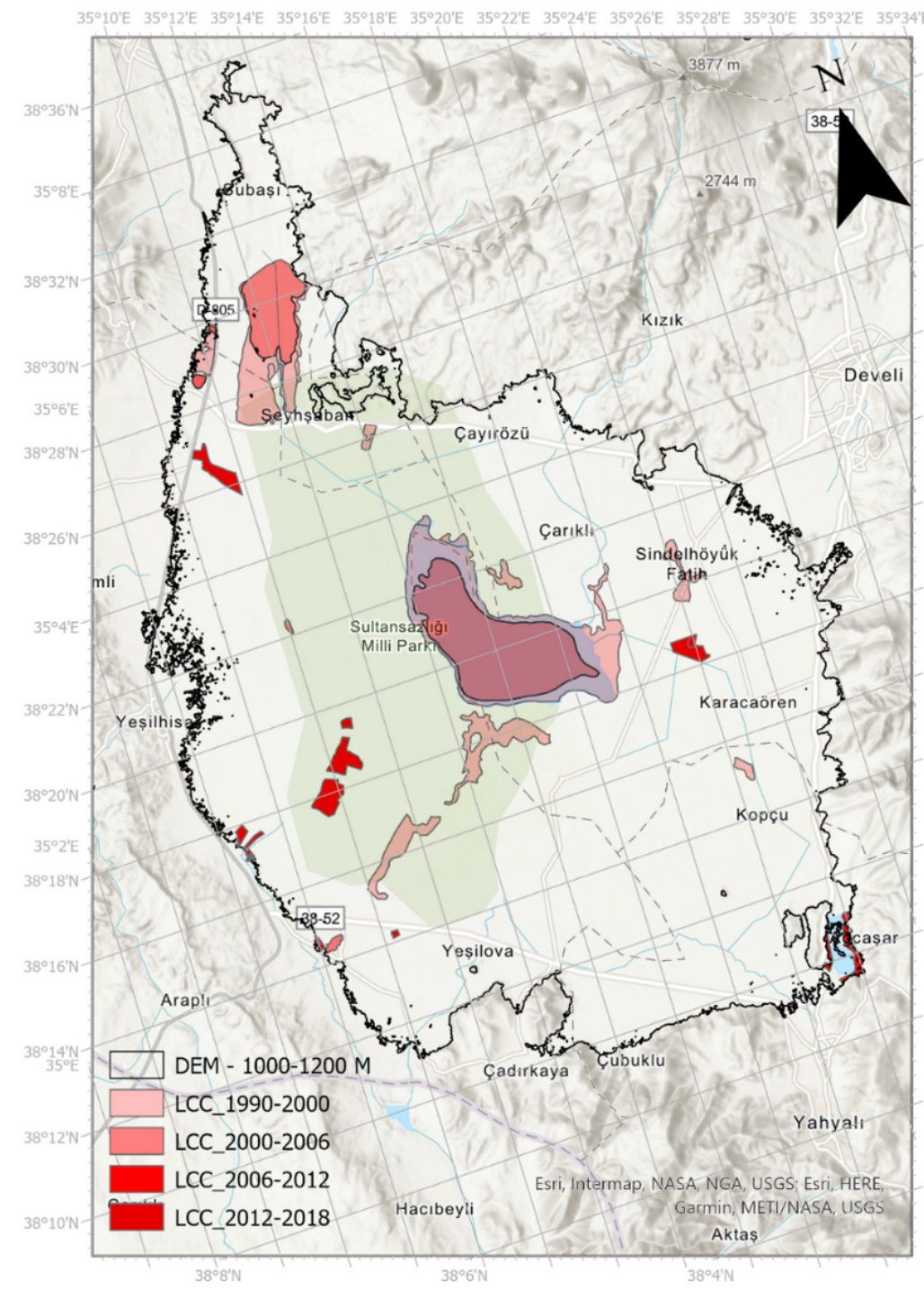

Figure 3

Data of the study. 

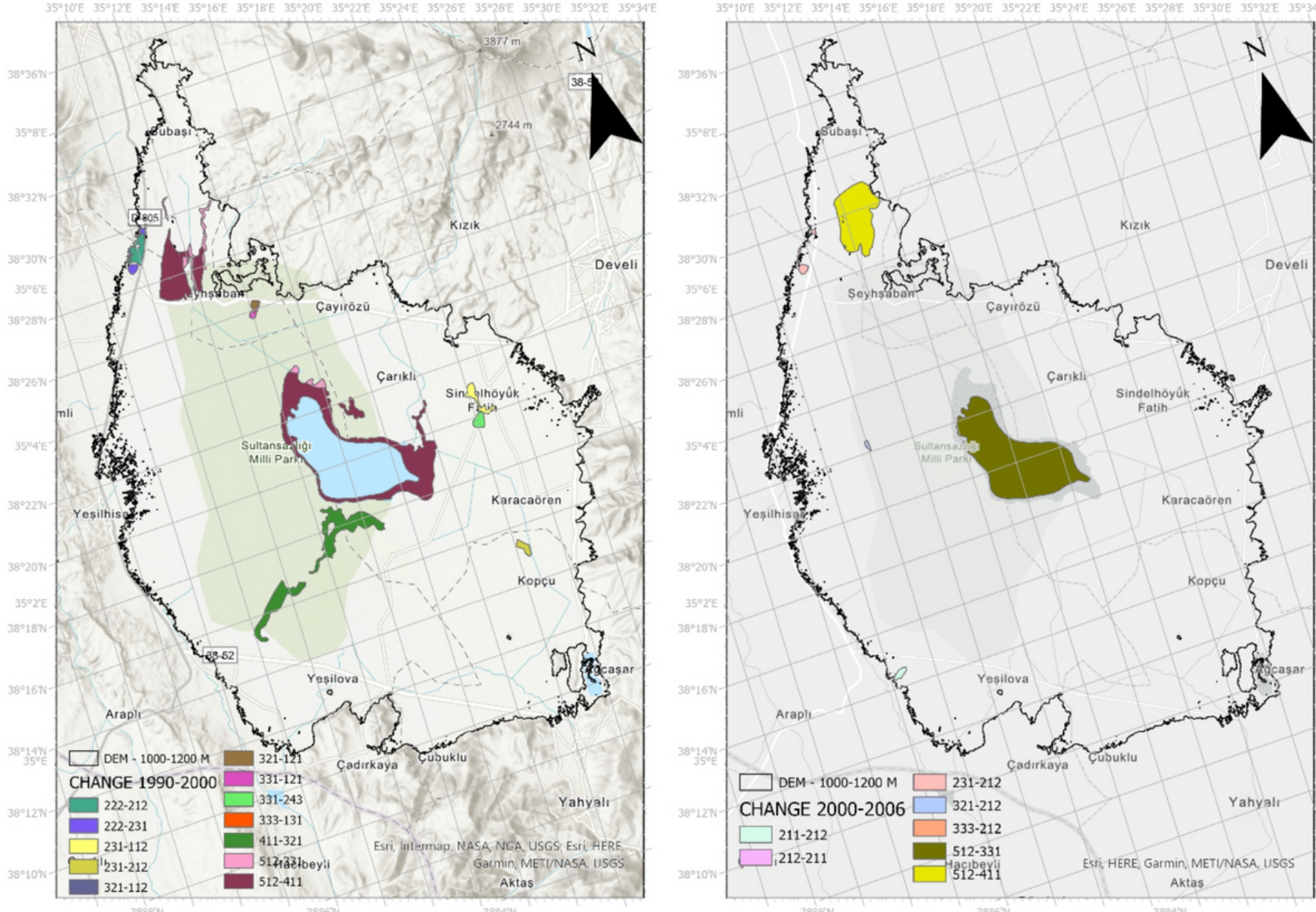

Figure 4

CHAs for the study area between 1990-2018 in four periods. 

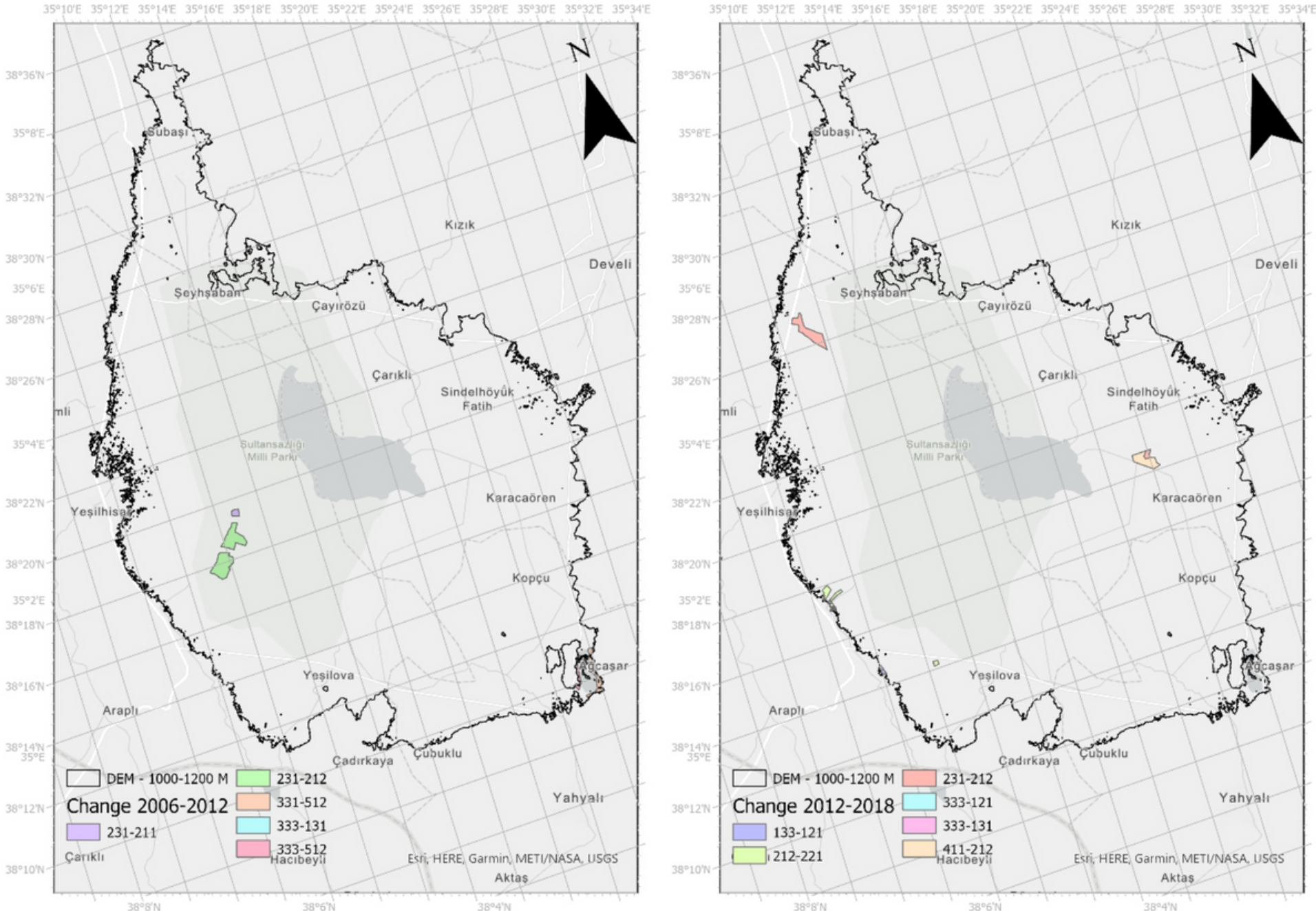

Figure 5

The changes of the land cover classes for the periods as 1990-2000, 2006-2012, 2012-2018. 


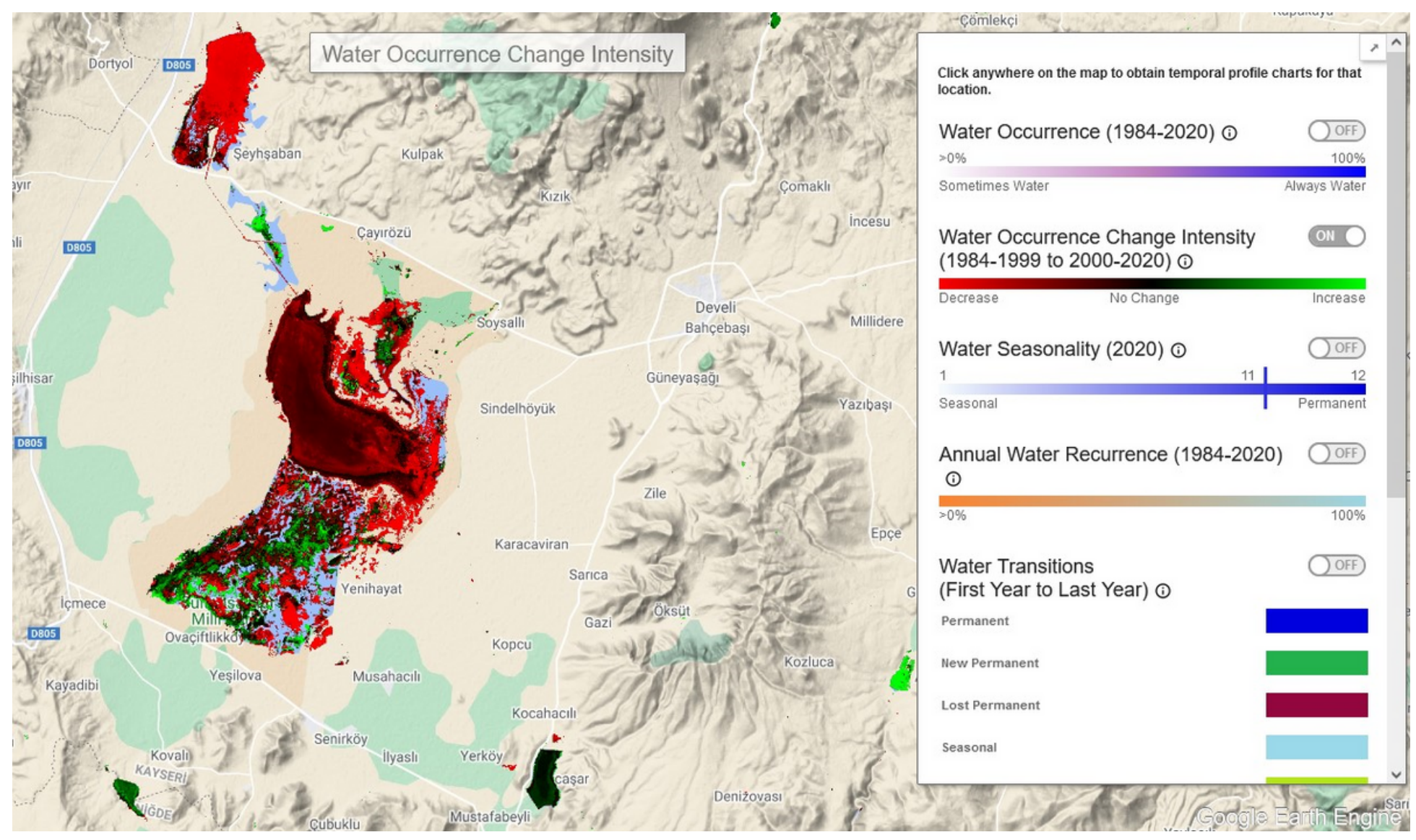

\section{Figure 6}

Water Occurence Change Intensity between 1984-2020 in the Yay Lake (in the middle) of the Sultan Marshes and the Çöl Lake (in the north) (Source: https://global-surface-water.appspot.com/map). 


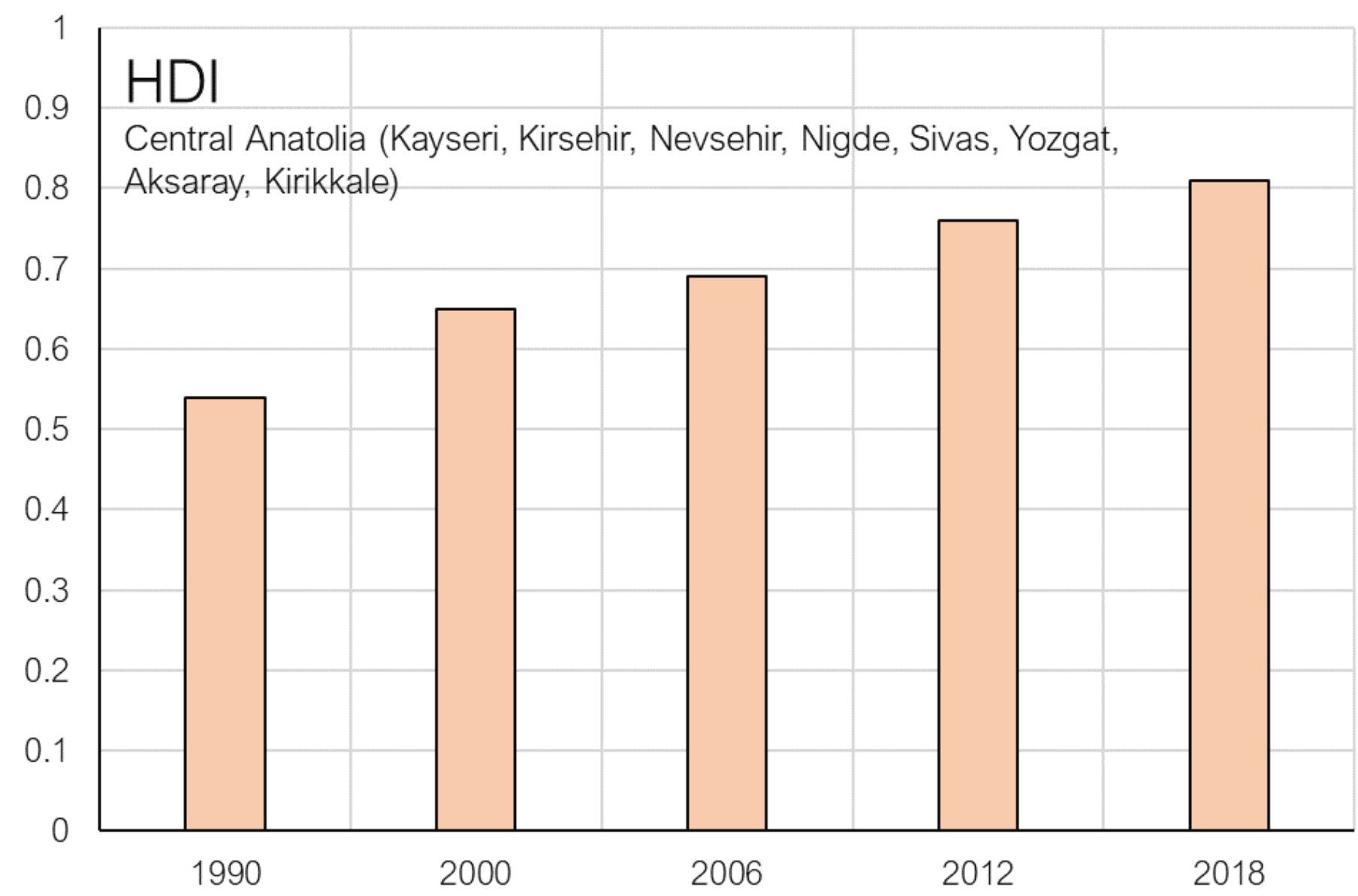

Figure 7

Subnational Human Developed Index of the regions including Central Anatolia (Kayseri, Kirsehir, Nevsehir, Nigde, Sivas, Yozgat, Aksaray, Kirikkale) between 1990 and 2018. 

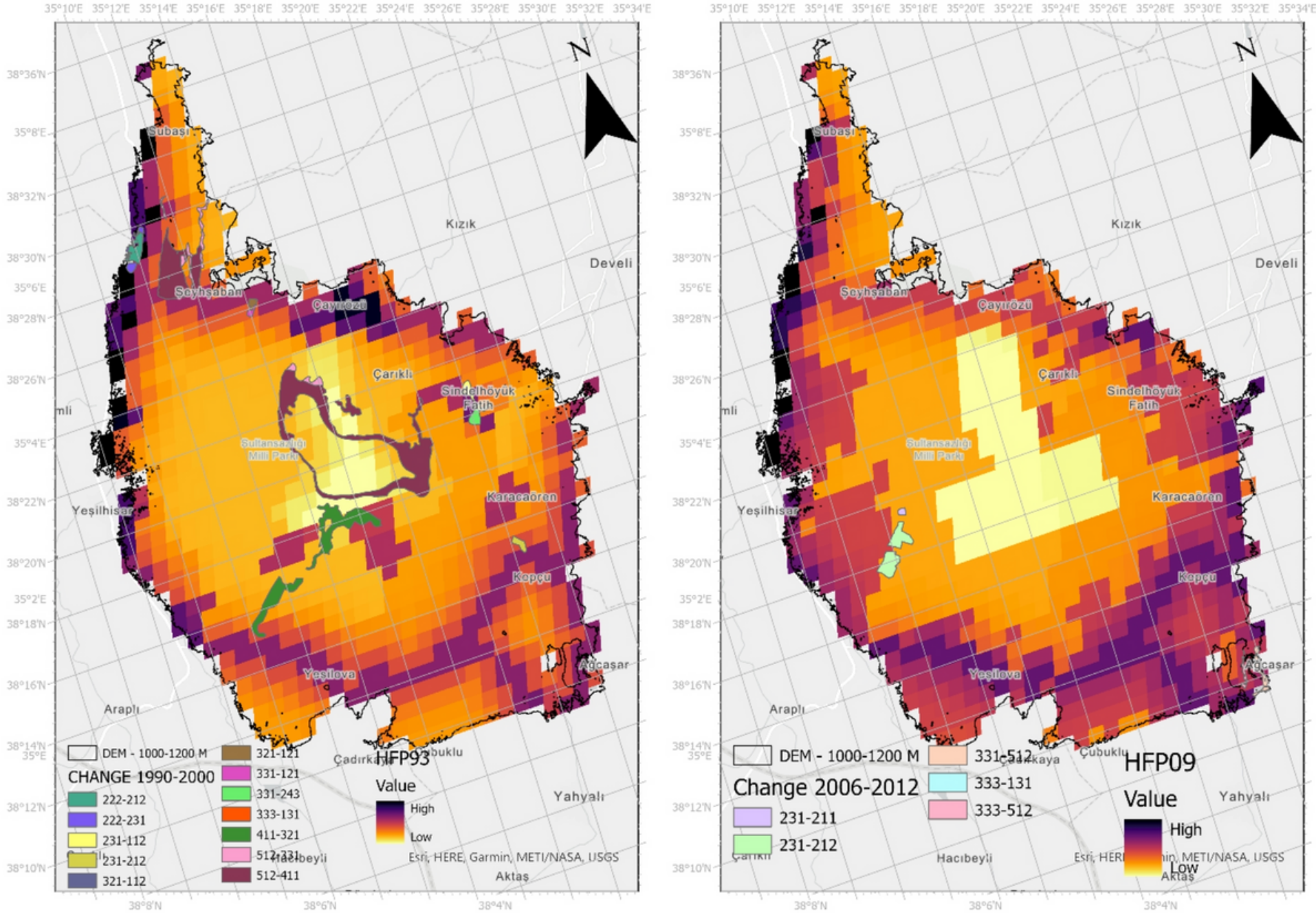

\section{Figure 8}

The Human Footprint for 1993 and 2009 with the CHAs (1990-2000 and 2006-2012) in and around the Sultan Marshes. 


\section{Turkey}

4

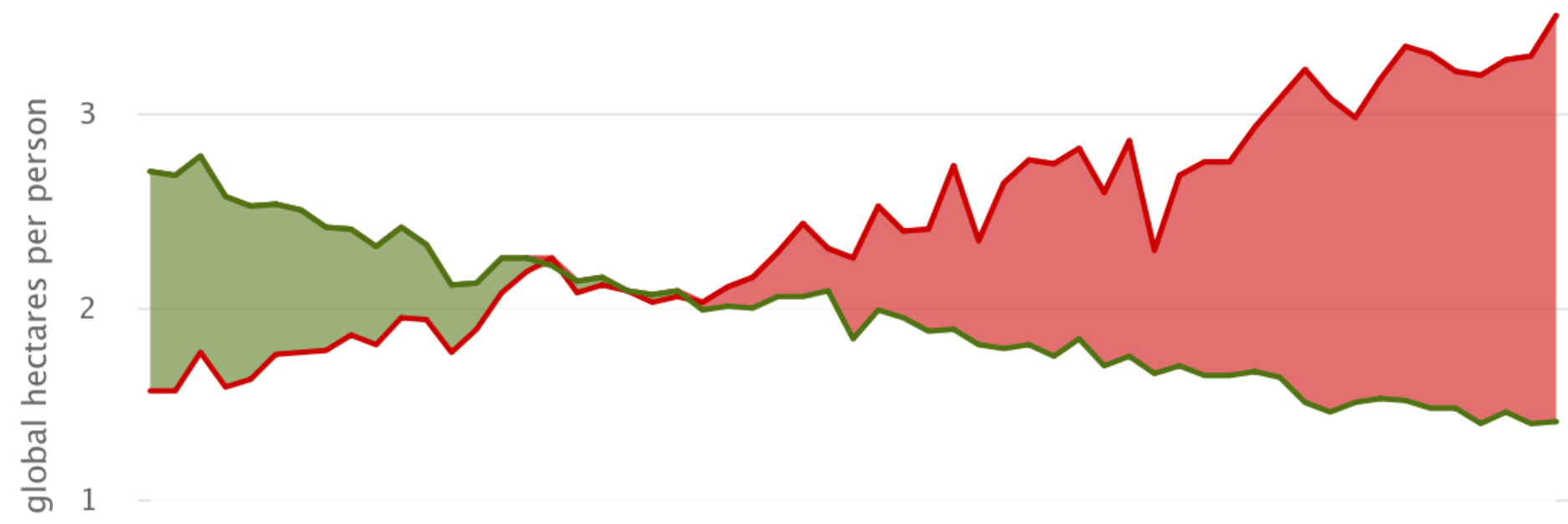

0 9.

- Ecological Footprint - Biocapacity Ecological Deficit Ecological Reserve

Global Footprint Network, 2021 National Footprint and Biocapacity Accounts

Figure 9

The footprint of Turkey (1961-2017) (National Footprint and Biocapacity Accounts 2021). 